\title{
REPRODUCTION IN THE LONG-TONGUED BAT, GLOSSOPHAGA SORICINA
}

\section{PREIMPLANTATION DEVELOPMENT AND HISTOLOGY OF THE OVIDUCT}

\author{
J. J. RASWEILER IV* \\ Section of Genetics, Development and Physiology, \\ Division of Biological Sciences, Cornell University, \\ Ithaca, New York
}

(Received 12th October 1971, accepted 21st March 1972)

\begin{abstract}
Summary. The reproductive biology of the neotropical bat, Glossophaga soricina, was investigated histologically using 103 animals removed from an experimental laboratory colony at daily intervals during their cycle, as determined by vaginal smears, or following mating.

The animals were polyoestrous, with 22- to 26-day cycles (mode = 24). Ovulation was spontaneous and was followed by a functional luteal phase, terminated by menstruation. Cyclic changes in the oviducal epithelium were pronounced and included an unusual vacuolation of the secretory cells with material that was PAS-, Alcian blue- and Azure A( $\mathrm{pH} \mathrm{4.5)} \mathrm{negative.}$

One oviduct usually exhibited evidence of preferential stimulation, particularly of the epithelium. Oestrual dilatation of the ampulla was restricted to the side of ovulation. The unilateral oviduct reaction may have resulted from hormones diffusing directly across points of 'fusion' of the ovary with the oviduct and mesosalpinx.

The tubal journey of the single fertilized ovum was prolonged. The blastocyst stage was reached on Days 9 to 10 and loss of the zona pellucida occurred in the oviduct on Days 11 to 12 . The ovum entered the uterotubal junction between Days 12 and 14. Degenerating ova and free zonae could not pass the ampullary-isthmic junction. Implantation occurred before Day 15 within the uterotubal junction. The lengthy tubal journey of the ovum is presumably related to the fact that menstruation in this species occurs in close temporal proximity to ovulation.
\end{abstract}

\section{INTRODUCTION}

Although the Phyllostomatid bats are one of the largest families of mammals (Anderson \& Jones, 1967), our knowledge of reproduction in this important group is based on a limited amount of field-collected material (Hamlett,

* Present address: Department of Anatomy, College of Physicians and Surgeons of Columbia University, 630 West 168th Street, New York, N.Y. 10032, U.S.A. 
1934a, b, 1935; Wislocki \& Fawcett, 1941 ; Bradshaw, 1962; Tamsitt \& Valdivieso, 1965; Fleming, 1971).

The reported occurrence of both menstruation and interstitial implantation in Glossophaga soricina (Hamlett, 1934a, b, 1935) suggested that these bats might possess unique potential for development as an experimental species. A study was, therefore, undertaken to establish the sequence of events in the female reproductive tract at carefully timed intervals during the cycle and early gestation. The observations presented here deal primarily with the oviduct.

\section{MATERIALS AND METHODS}

\section{Animal care and management}

Detailed methods for the maintenance of this species in the laboratory are described elsewhere (Rasweiler, 1970, 1972a, 1973).

Females were housed in groups of fifteen to twenty per cage. When they were to be mated, one to three males were introduced into each cage.

\section{Vaginal smears}

The animals were captured between 08.00 and 11.00 hours each day to procure vaginal smears. Because of the small size of the bats (mean non-pregnant weight $=10.6 \mathrm{~g}$ ), the smears had to be obtained by aspirating distilled water introduced into the vagina with specially designed microeyedroppers (Rasweiler, 1970). Micropipettes suitable for this purpose are now commercially available (Disposable Micropipettes by Kensington Scientific Corp., Oakland, Calif. 94608).

The smears were examined fresh or dried, fixed in ether: ethanol $(1: 1)$ and then stained by the Papanicolaou technique (Lillie, 1965).

\section{Distribution of reproductive material}

The study was based on 103 G. soricina killed between 10.00 and 13.00 hours at daily intervals between mating, or oestrus, and Day 24 of pregnancy ( $\mathrm{n}=$ fifty-eight), pseudopregnancy ( $\mathbf{n}=$ nine), or the cycle $(\mathrm{n}=$ thirty-six). Two to eight animals were killed on each day. At least two animals per day were pregnant. Gaps or poorly represented intervals occurred between Days 8 to 10 and 15 to 18 of the cycle.

\section{Histological procedures}

The bulk of the reproductive tracts were fixed in Helly's fluid. However, one or two tracts representing each day of pregnancy were preserved in Carnoy's fluid for histochemical purposes. The tissues were embedded in paraffin wax and sectioned at $5 \mu \mathrm{m}$.

The Helly-fixed material was stained with haematoxylin and eosin, Masson's

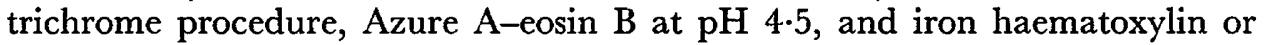
iron haematoxylin-periodic acid-Schiff (PAS) procedure. The Carnoy-fixed material was stained with the PAS procedure, with the Azure B method of Flax \& Himes (1952), and with Alcian blue 8GX at pH 2.0. Details of the tissue treatment procedures are described elsewhere (Rasweiler, 1970, 1972b). 


\section{RESULTS}

\section{Interpretation of vaginal smears}

The study of vaginal smears from fifteen mated animals revealed considerable individual variation, but the cytological changes fell into a general pattern around the time of oestrus (Table 1). Dating of the cycle in nonpregnant animals depended upon recognition of the smears in the series from each animal that best exemplified these characteristics. These vaginal changes were not abrupt but took place gradually over a 2- to 4-day period and the correct timing of oestrus could probably have varied by as much as $\pm 72 \mathrm{hr}$.

In thirty-two of thirty-six animals which had detectable vaginal cycles, the

TABLE 1

DATING OF VAGINAL OESTRUS IN $G$. soricina

\begin{tabular}{l|l}
\hline \multicolumn{1}{c|}{ Time in cycle } & \multicolumn{1}{c}{ Characteristics of vaginal smear } \\
\hline A. Day $1^{*}$ or 2 & $\begin{array}{l}\text { Contained the largest epithelial cells with the most } \\
\text { irregular borders. Showed the greatest tendency for } \\
\text { the epithelial cells to lie singly. }\end{array}$ \\
$\begin{array}{l}\text { B. The day subsequent } \\
\text { to A (i.e., Day 2 or 3) }\end{array}$ & $\begin{array}{l}\text { The epithelial cells tended to lie in clumps or } \\
\text { sheets. The epithelial cells contained abundant } \\
\text { cytoplasmic vacuoles. The epithelial cells tended to } \\
\text { be smaller and rounder than those of the previous } \\
\text { day's smear. }\end{array}$ \\
\hline
\end{tabular}

* Day 1 = the day on which spermatozoa would be present in the vaginal smear if mating had been permitted, and a newly ovulated egg would be present in the oviduct.

timing of the cycles by smears was consistent with that arrived at by subsequent histological comparison of the tracts with those from mated animals. Another six animals appeared to run cycles, but exhibited abnormalities of uterine histology and were not incorporated in the study. No vaginal cycle could be detected in eight animals.

Events in pregnant animals were timed with respect to the first appearance of spermatozoa in the vaginal smear.

\section{Ovarian and uterine biology}

The study of sexually segregated females revealed that $G$. soricina ovulates spontaneously, is polyoestrous with a cycle of 22 to 26 days (mode $=24$ days), and possesses a functional luteal phase. Bleeding and extensive desquamation of the uterine endometrium (i.e. true menstruation) occurs at, or very close, to the time of oestrus and ovulation. Most repair of the endometrium takes place after ovulation.

No evidence for the ovulation of more than one ovum per cycle was seen in any of the animals. The corpora lutea (CL) persisted for at least two cycles although by the end of the second cycle following their formation, many were difficult to identify.

Both ovaries were equally functional (Table 2), but there was a tendency towards alternation of ovulations. Theoretically, if ovulation occurred randomly, successive GL should have been in the same ovary $50 \%$ of the time and in 
TABLE 2

DISTRIBUTION OF CORPORA LUTEA BETWEEN THE LEFT AND RIGHT OVARIES IN $G$. soricina

\begin{tabular}{l|c|c}
\hline \multirow{2}{*}{ Distribution pattern } & \multicolumn{2}{|c}{ Total no. of corpora lutea } \\
\cline { 2 - 3 } & Left ovary & Right ovary \\
\hline Single CL* & 56 & 59 \\
Two cL $\dagger$ & 10 & 10 \\
Two successive CL & 40 & 44 \\
Three successive CL $\$$ & 9 & 0 \\
Total & 115 & 113 \\
\hline
\end{tabular}

* Since all normal reproductive tracts contained a minimum of two cL, there was at least one corpus luteum in the opposite ovary as well.

$\dagger$ These cL were not from successive ovulations.

$¥$ No statistical significance relative to the other distribution patterns should be inferred, since CL that were three cycles old were usually difficult to identify and the data are therefore probably incomplete.

TABLE 3

STAGES OF DEVELOPMENT AND LOCATION OF THE OVA IN G. soricina

\begin{tabular}{|c|c|c|c|}
\hline $\begin{array}{c}\text { Age of ovum } \\
\text { (days) }\end{array}$ & $\begin{array}{l}\text { No. of } \\
\text { animals }\end{array}$ & Stage of development & $\begin{array}{c}\text { Location of } \\
\text { ovum }\end{array}$ \\
\hline $\begin{array}{l}0 \text { to } 1 \\
1 \text { to } 2 \\
2 \text { to } 3 \\
3 \text { to } 4 \\
4 \text { to } 5 \\
5 \text { to } 6 \\
5 \text { to } 6 \\
6 \text { to } 7 \\
6 \text { to } 7 \\
7 \text { to } 8 \\
8 \text { to } 9 \\
9 \text { to } 10 \\
10 \text { to } 11 \\
11 \text { to } 12 \\
11 \text { to } 12 \\
12 \text { to } 13 \\
12 \text { to } 13 \\
12 \text { to } 13 \\
13 \text { to } 14 \\
13 \text { to } 14 \\
14 \text { to } 15\end{array}$ & $\begin{array}{l}3 \\
3 \\
2 \\
3 \\
2 \\
1 \\
1 \\
1 \\
1 \\
2 \\
2 \\
2 \\
2 \\
2 \\
1 \\
1 \\
1 \\
1 \\
1 \\
4 \\
4\end{array}$ & $\begin{array}{l}\text { Pronuclear stage } \\
1 \text { cell } \\
2 \text { cell } \\
4 \text { cell } \\
4 \text { cell } \\
4 \text { cell } \\
8 \text { cell } \\
8 \text { cell } \\
16 \text { to } 32 \text { cell } \\
16 \text { to } 32 \text { cell } \\
32 \text { to } 64 \text { cell } \\
\text { Blastocyst* } \\
\text { Blastocyst } \\
\text { Blastocyst } \\
\text { Blastocyst (-ZP) } \dagger \\
\text { Blastocyst (-ZP) } \\
\text { Blastocyst (-ZP) } \\
\text { Implanting blastocyst } \\
\text { Blastocyst (-ZP) } \\
\text { Implanting blastocyst } \\
\text { Implanting blastocyst }\end{array}$ & $\begin{array}{l}\text { Ampulla } \\
\text { Ampulla } \\
\text { Ampulla } \\
\text { Ampulla } \\
\text { Ampulla } \\
\text { Ampulla } \\
\text { Ampulla } \\
\text { Ampulla } \\
\text { Ampulla } \\
\text { Ampulla } \\
\text { Ampulla } \\
\text { Ampulla } \\
\text { Ampulla } \\
\text { Ampulla } \\
\text { UTJ, }, ~ \\
\text { Ampulla } \\
\text { UTJ } \\
\text { UTJ } \\
\text { UTJ } \\
\text { UTJ } \\
\text { UTJ }\end{array}$ \\
\hline
\end{tabular}

* One animal contained a very early blastocyst.

$\dagger(-\mathrm{ZP})=$ zona pellucida had been shed.

$\ddagger \mathrm{UTJ}=$ uterotubal junction

This is the only pregnant individual in which the discarded zona pellucida had entered the uterotubal junction with the blastocyst. 
the opposite ovary for the remaining $50 \%$. In actuality, $40.8 \%$ were in the same ovary and $59.2 \%$ were in the opposite ovary.

\section{Tubal journey of the ovum}

The rate of development and the location of fertilized eggs in the reproductive tract may be ascertained from Table 3.

In $G$. soricina, the ovum loses its zona pellucida in the oviduct, and the zona does not normally pass into the uterus with the blastocyst. Similarly, reasonably intact but degenerating unfertilized eggs are retained at the ampullaryisthmic junction. The zonae usually persist for at least one full cycle and occasionally those from two previous cycles, along with a recently ovulated egg, have been observed in the oviducts of a single bat. The eventual fate of old zonae appears to be slow shrinkage and/or dissolution associated with fragmentation within the oviduct. In only two of the 103 animals examined were zonae observed in the uterus rather than the oviduct. At least one of these tracts may have been abnormal since the ovum apparently had entered the uterotubal junction prematurely (i.e. on Day 11 -see Table 3 ).

In view of the fact that dissolution of the zona pellucida is such a slow process in this species, its contribution to loss of the zona by the blastocyst would appear to be questionable. Comparison of zona-encased morulae and blastocysts indicated that the zona expands and thins considerably during blastocyst formation. Possibly, expansion of the blastocyst continues until the limit of the elasticity of the zona is reached when rupture occurs.

The blastocysts normally do not enter the uterine lumen. Rather, they lodge within the uterotubal junction, which runs a lengthy course through the fundal endometrium, and penetrate from there into the surrounding endometrium. Therefore, implantation is not interstitial from the uterine lumen, as previously reported (Hamlett, 1934a, 1935), but is more appropriately termed 'uterotubal' (Rasweiler, 1970).

\section{Anatomical relationships of the ovary and oviduct}

Glossophaga soricina is unique among the mammals so far studied in that there is usually a differential stimulation of the two oviducts. This has been noted at every stage of the cycle.

The unilateral oviduct reaction may be related to some unusual anatomical relationships of the ovaries and oviducts. The oocytes are not distributed evenly throughout the periphery of the ovary but are congregated in a capshaped zone on the medial side (Pl. 1, Figs 1 and 2). The germinal epithelium only covers this latter area. When ovulation occurs, the point of follicular rupture is usually through the oocyte zone. The remainder of the ovary is covered by a layer of connective tissue and serosa. Each ovary is partially enclosed by a cup-shaped pocket formed from the mesosalpinx as the oviduct makes a long sweep along the anterior, lateral, posterior and then medial aspects of the ovary. Points of fusion of the wall of the ovary with the mesosalpinx (Pl. 1, Fig. 1) and the wall of the oviduct (Pl. 1, Fig. 2) occur.

\section{Cytological organization of the oviduct}

The oviducal epithelium is composed primarily of ciliated cells, which pre- 


\section{EXPLANATION OF PLATES 1 TO 3}

\section{PLATE 1}

Frg. 1. Section of ovary of $G$. soricina demonstrating the congregation of oocytes on the medial side (upper side in photo), and the fusion of the ovary with the mesosalpinx. $\times 30$.

FIG. 2. Section illustrating the fusion of the ovary with the wall of the oviduct in $G$. soricina. Note the lack of oocytes in the portion of ovary included in this field. $\times 65$.

FIG. 3. Section of the fimbria $(F)$ and infundibulum (I) of the oviduct on Day 17 of the cycle in G. soricina. Masson's trichrome. $\times 544$.

Fig. 4. Section of the ampulla of the oviduct on Day 17 of the cycle in G. soricina. Haematoxylin and eosin. $\times 544$.

FIG. 5. Section of the fimbria of the oviduct on Day 1 of pregnancy in $G$. soricina. Note the marked hypertrophy of the epithelium compared with its condition on Day 17 of the cycle (Fig. 3). A number of B cells (arrows) are evident. Azure A-eosin B. $\times 544$.

FIg. 6. Section of the oviducal infundibular of $G$. soricina (Day 1 of pregnancy) containing abundant, deeply stained mast cells (MC) in the lumen. Note the vacuoles (arrows) present in many of the secretory epithelial cells. Azure A-eosin B. $\times 544$.

\section{PLATE 2}

Fig. 7. Section of the oviducal ampulla on the stimulated side (Day 20 of the cycle) in G. soricina. Note the vacuoles that had begun to develop in this oviduct: they were absent from the opposite ampulla (Fig. 8). Haematoxylin and eosin. $\times 544$.

Fig. 8. Section of the oviducal ampulla on the non-stimulated side (Day 20 of the cycle) in $G$. soricina which was proximal to the CL. Vacuoles are largely absent from the secretory cells. Haematoxylin and eosin. $\times 544$.

FIg. 9. Section of the oviducal ampulla proximal to the new cL (Day 1 of pregnancy) in G. soricina. The lumen of this oviduct was markedly dilated with fluid. Azure A-eosin B. $\times 544$.

Fig. 10. Section of the oviducal ampulla contralateral to the new CL (Day l of pregnancy) in G. soricina. Note the greater prominence of the vacuoles in the secretory cells of this as opposed to the opposite oviduct (Fig. 9). Azure A-eosin B. $\times 544$.

Fig. 11. Section of the oviducal ampulla proximal to the CL on Day 6 of pregnancy in $G$. soricina. Note the marked vacuolation of the secretory cells. Azure A-eosin B. $\times 544$.

Fic. 12. Section of the oviducal ampulla contralateral to the ch on Day 6 of pregnancy in G. soricina. The vacuoles in the secretory cells are poorly developed compared with those in the opposite oviduct (Fig. 11). Azure A-eosin B. $\times 544$.

\section{PLATE 3}

FIG. 13. Section of the oviducal ampulla proximal to the cL on Day 13 of pregnancy in G. soricina. Note the lack of vacuolated areas in the epithelial cells and the assumption, by the latter of their 'peg cell' form. Masson's trichrome. $\times 544$.

Frg. 14. Section of the oviducal ampulla contralateral to the CL on Day 13 of pregnancy in $G$. soricina. Many of the secretory cells still retain vacuolated areas which are lacking in the opposite ampulla (Fig. 13). Note also the difference in the vesicularity of the secretory cell nuclei. Masson's trichrome. $\times 544$.

Fig. 15. Section of the oviducal fimbria on Day 12 of pregnancy in G. soricina. Note the regressed condition of the epithelial cells relative to an earlier stage (PI. 1, Fig. 5). Masson's trichrome. $\times 544$.

Frg. 16. Section of the oviducal ampulla proximal to the cL on Day 6 of pregnancy in $G$. soricina. PAS-toluidine blue. Secretory material is stained only at the apical border of the secretory cells. The prominent vacuolated areas are PAS-negative. $\times 544$.

FIG. 17. Section of the oviducal ampulla proximal to the cL on Day 12 of pregnancy in $G$. soricina. PAS-toluidine blue. The reaction of this oviduct to staining with PAS is relatively slight. $\times 544$.

FIg. 18. Section of the oviducal ampulla contralateral to the CL on Day 12 of pregnancy in $G$. soricina. PAS-toluidine blue. Due to the presence of glycogen, the reaction to staining with PAS is much greater in the secretory cells of this oviduct compared with the opposite one (Fig. 17). $\times 544$. 

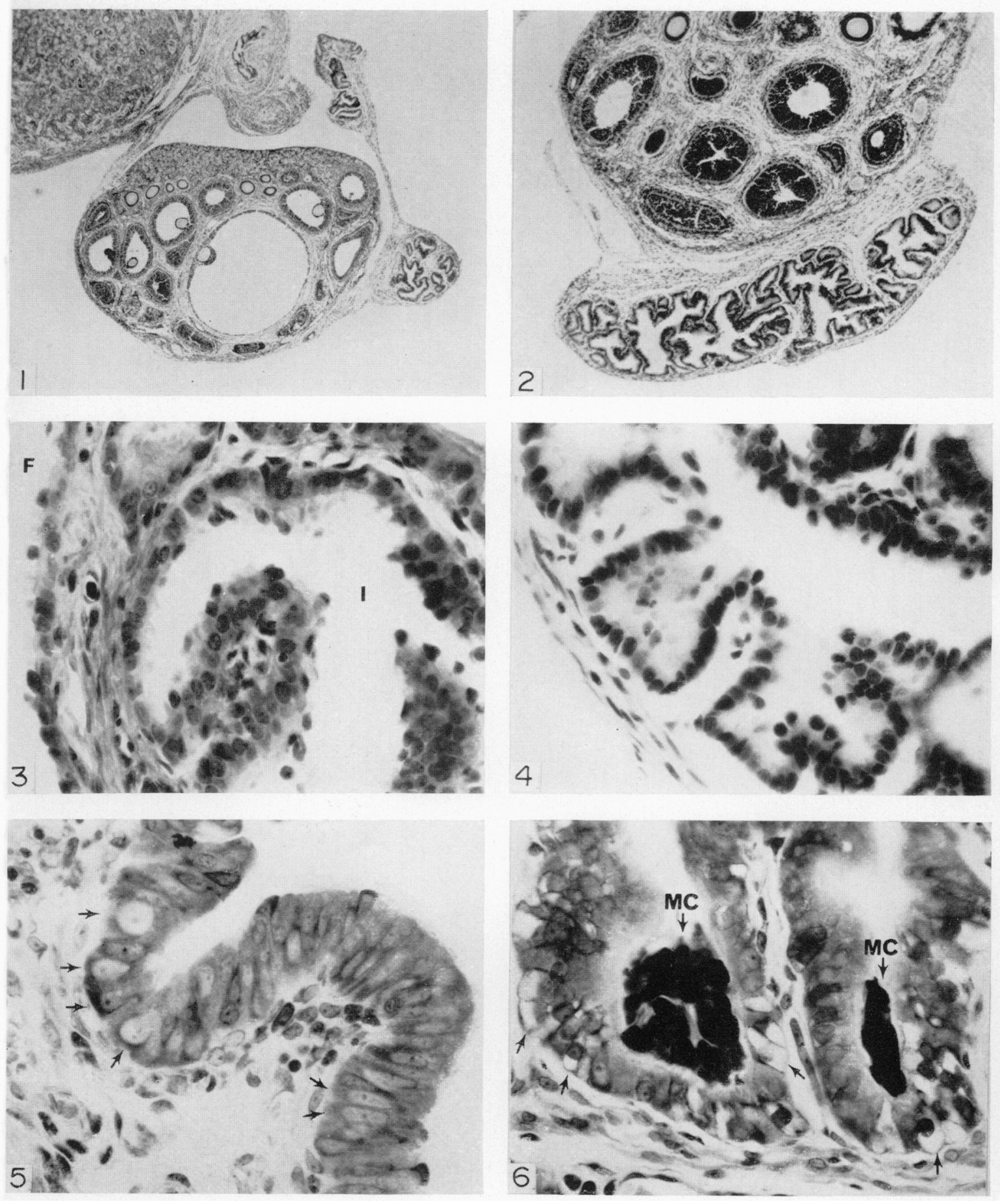
Fó -6. है के

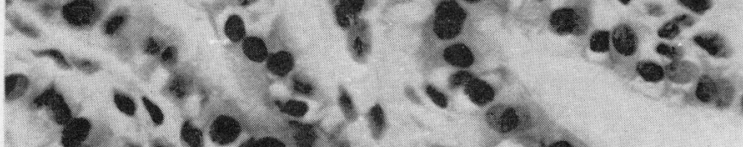
$2.3007,5=3$ $700.05 \%=\frac{2}{3}$
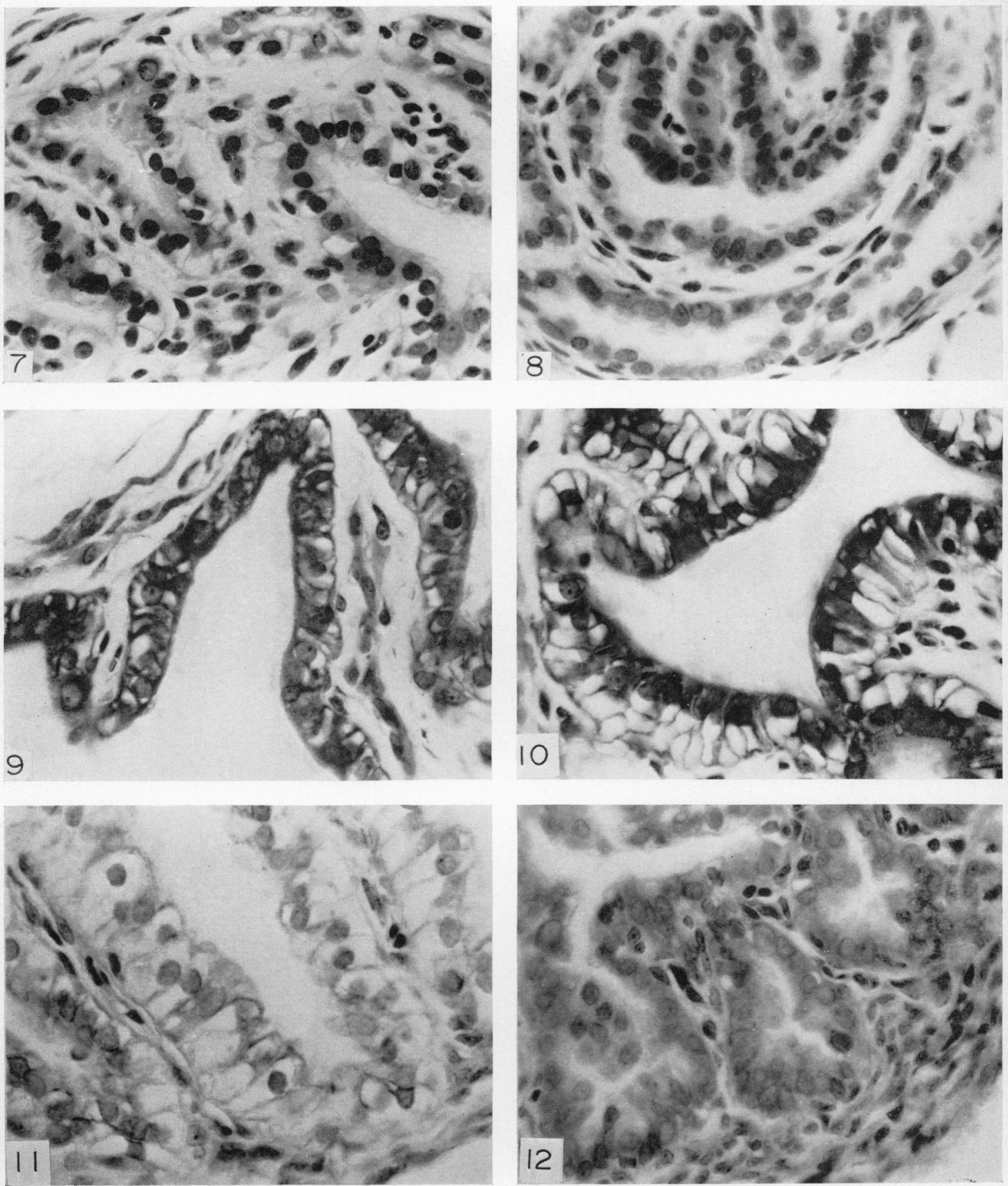
A.

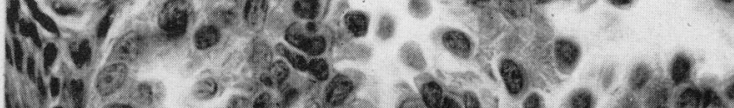

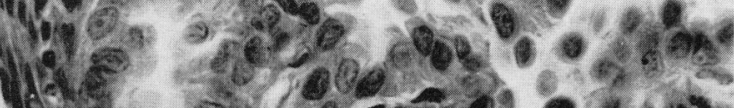

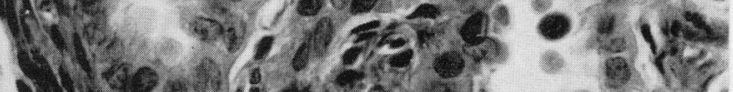

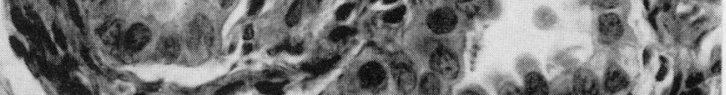

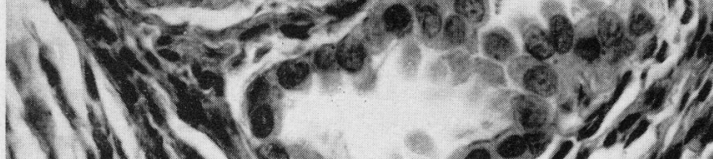

1. 1130

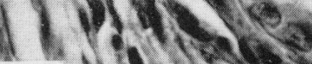

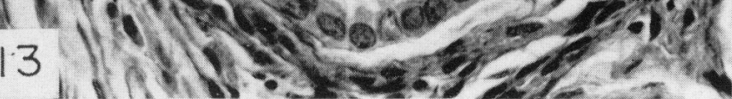
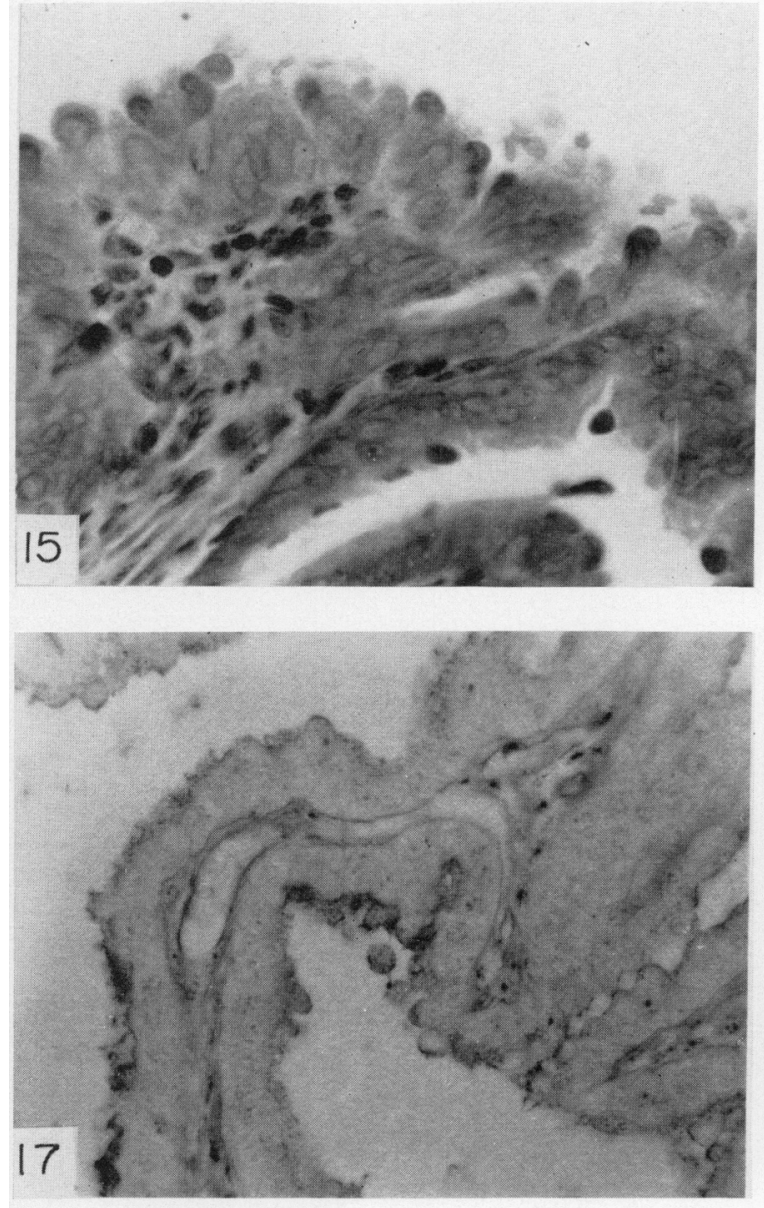
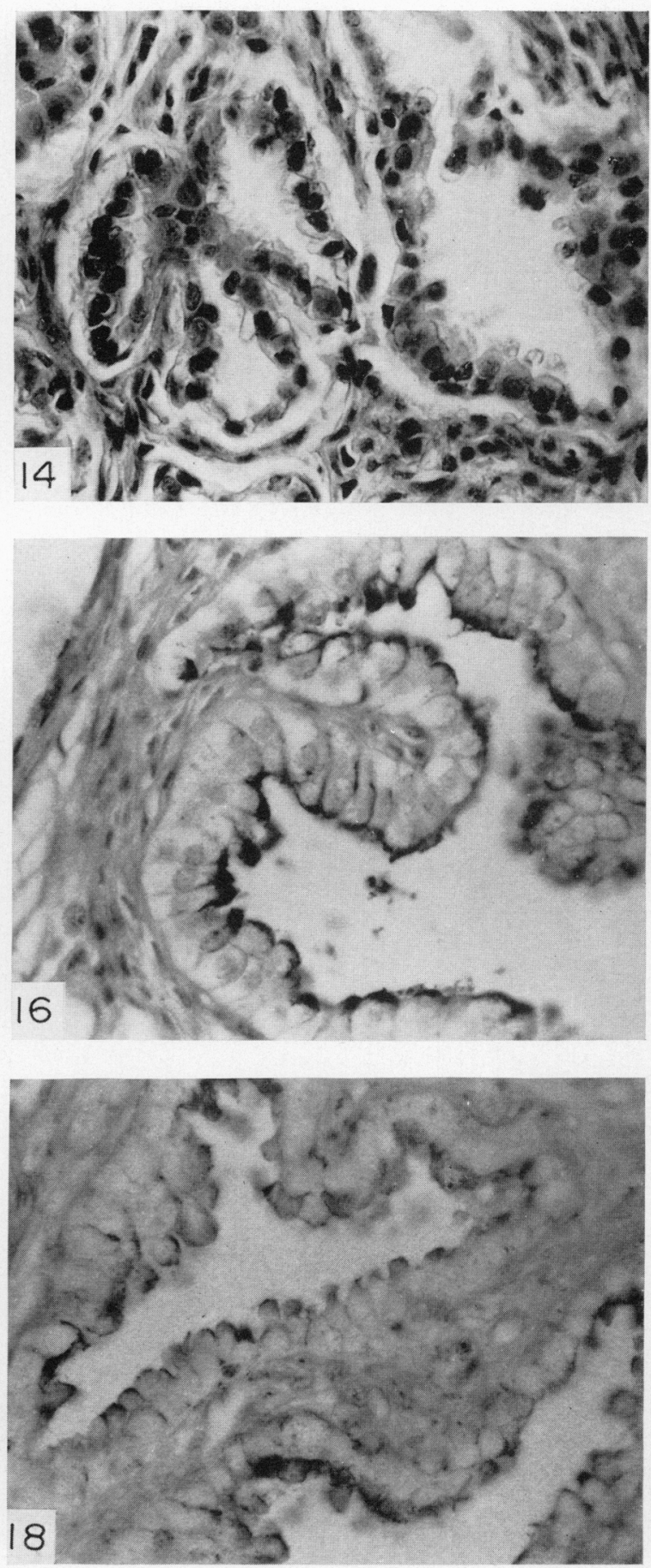
dominate in the preampulla, and secretory cells, which predominate in the ampulla (PI. 1, Figs 3, 5, 6 and Pl. 2, Fig. 11), isthmus and junctura (= the last segment of oviduct; terminology of Nilsson \& Reinius, 1969). Particularly in the ampulla, the secretory cells became bloated with a material that was not preserved and/or stained by the histological methods used (Pl. 2, Figs 9, 10 and 11, and Pl. 3, Fig. 16). In their regressed condition, the secretory cells (Pl. 3, Fig. 13) resembled the typical 'peg cells' commonly observed in the oviducts of other species (Nilsson \& Reinius, 1969; Woodruff \& Pauerstein, 1969).

At about the time of oestrus, a third cell type was readily discernible in the preampulla. This was characterized by a large vesicular nucleus, prominent nucleoli, and a very deeply basiphilic (attributable to the presence of abundant RNA), PAS-negative cytoplasm (Pl. 1, Figs 5 and 6). These were termed Bcells. Both ciliated and non-ciliated forms were observed, although the latter were rare.

The frequency of ciliated cells and degree of vacuolation of the secretory cells decrease in the isthmus. There were no ciliated cells in the junctura and only occasional vacuoles in the secretory cells of the extramural junctura.

Between the end of the oviducal junctura and the uterine lumen lies a narrow tube which lacks the fibrous lamina propria and the tunica muscularis of the junctura, and instead is underlain by uterine endometrial stroma. Much of this tubular segment which is the normal site of attachment of the ovum at implantation is lost during menstruation. It is probably best considered as a welldeveloped uterine portion of the uterotubal junction.

Histological changes in the oviduct during the reproductive cycle and early pregnancy

During the first 2 weeks after ovulation, the histology of the oviduct did not differ whether or not the eggs were fertilized.

When attention was restricted to the oviduct showing preferential stimulation, cyclic patterns became apparent in several parameters (Text-fig. 1A to D). Since it was not possible to measure most of these objectively, an attempt was made to estimate them subjectively using scoring systems that ranged from 0 to +5 .

The oviduct was usually in its most regressed condition on Days 16 and 17 of the cycle. In the event of pregnancy, the oviduct remained like this until at least Day 24, the latest stage examined. The height of the epithelium of the infundibulum and ampulla ranged between 7 and $13 \mu \mathrm{m}$, and many of the secretory cells possessed bulging apical portions or 'secretory domes' into which the nuclei had frequently been squeezed (Text-fig. 1B and Pl. 1, Figs 3 and 4). Thereafter, a gradual hypertrophy of the preampullary epithelium became evident in non-pregnant animals. By Day 1 , the epithelium had reached its greatest height, 20 to $30 \mu \mathrm{m}$ in the fimbria (Pl. 1, Fig. 5) and 12 to $25 \mu \mathrm{m}$ in the infundibulum (Pl. 1, Fig. 6). There was a concomitant enlargement of the nuclei and a decrease in the nuclear to cytoplasmic ratio which resulted in less crowding of the nuclei in the epithelium.

About Day 19 or 20 of the cycle, the B-cells started to come into prominence (Text-fig. 1D); their nuclei were lighter and more vesicular, the nucleoli were more conspicuous, and the cytoplasm more basiphilic. Simultaneously, mast 
cells, eosinophilic leucocytes and monocytes began to appear in the lumen of the oviduct, particularly in the preampulla, with a peak being reached at about the time of oestrus (Pl. 1, Fig. 6). Although mast cells and eosinophils were commonly seen in both the epithelium and the lamina propria (Rasweiler, $1972 \mathrm{~b}$ ), there was little evidence to suggest that they could pass completely through the epithelium to enter the lumen. A more likely source would seem to be the peritoneal fluid in which they occurred in abundance.
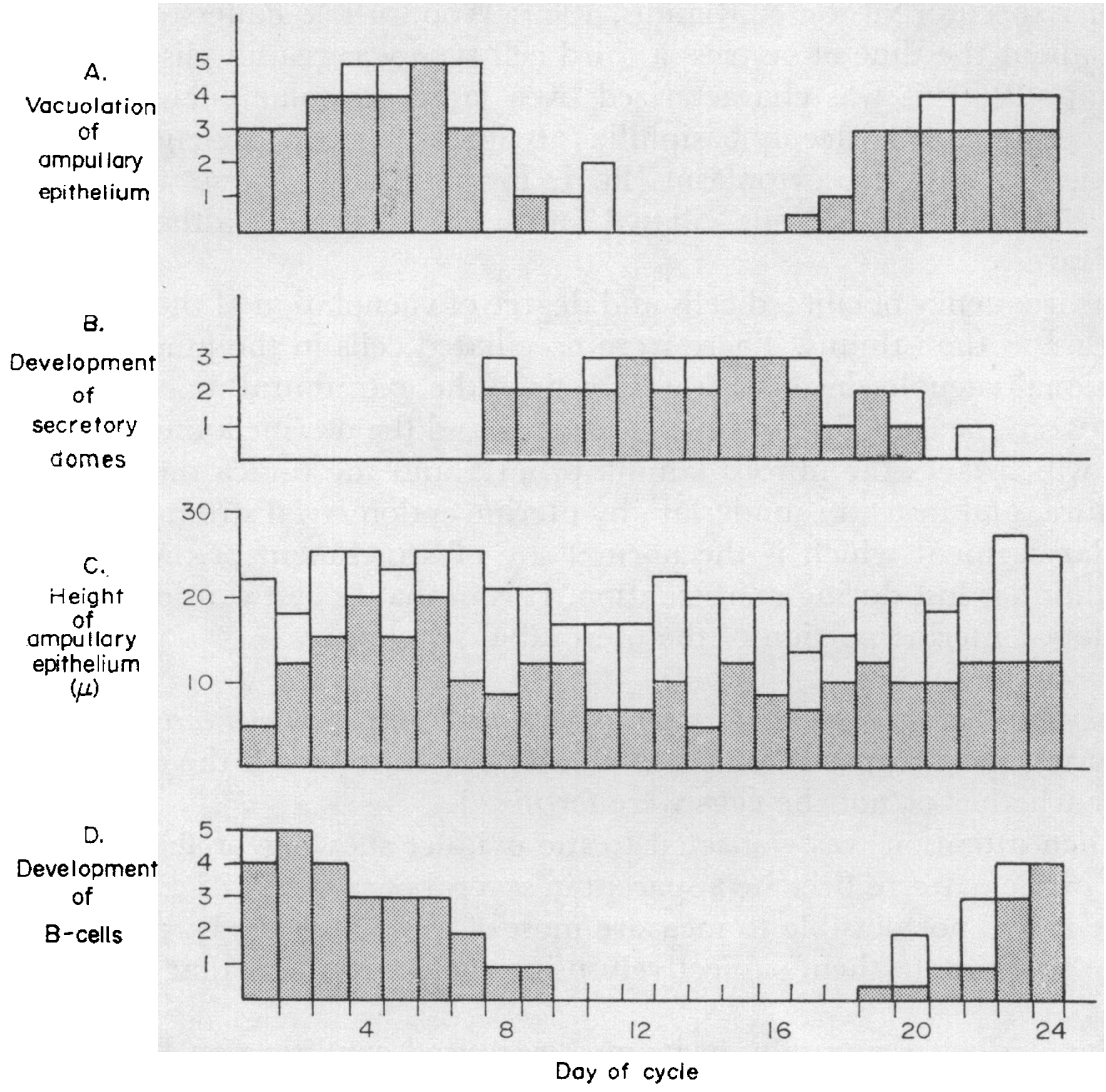

Text-rig. 1. Modifications in oviduct histology during the reproductive cycle of $G$. soricina. All data refer only to the oviduct showing preferential stimulation (see text for details). The open boxes indicate the range observed when differences were noted between animals killed on the same day.

Mitotic figures were noted in the oviducal epithelium between Days 19 and 2 , but their relative abundance varied tremendously between animals.

By Days 19 and 20 of the cycle, prominent vacuolated areas appeared within the cytoplasm of many of the secretory cells in the infundibulum and ampulla (Text-fig. 1A and Pl. 2, Fig. 7). These vacuoles continued to enlarge as oestrus approached thereby expanding the cells and permitting the nuclei to withdraw from the apical bulges. The bulges largely disappeared by Day 21 (Text-fig. 1B).

Vacuolation of the oviducal epithelium proximal to the ovary containing the most recently formed CL was maximal between Days 3 and 7 inclusive (Text-fig. 
1A, and PI. 2, Fig. 11). As the vacuoles disappeared, the secretory cells assumed their 'peg cell' form (Text-fig. 1B, Pl. 2, Fig. 12, and Pl. 3, Fig. 13). At first, the secretory domes were vacuolated but subsequently cytoplasm accumulated in them. As regression progressed, nuclei were squeezed into many of the projections. The development of the projections helped to maintain the height of the ampullary epithelium (cf. Text-fig. 1B and C), although the volume of the individual cells was markedly reduced.

The epithelium of the fimbria and infundibulum remained in a fully hypertrophied condition until Day 2 and then began to recede. By Day 8 , it was 8 to $15 \mu \mathrm{m}$ in height, the secretory cells had developed apical bulges, and few distinctive B-cells remained (Text-fig. 1D). At mid-cycle, the preampullary epithelium was only 7 to $12 \mu \mathrm{m}$ high (Pl. 3, Fig. 15).

\section{The unilateral oviduct reaction}

In thirteen of the nineteen tracts demonstrating preovulatory stimulation of the oviducts, a differential degree of vacuolation of the ampullary secretory cells was evident between the two ampullae (cf. Pl. 2, Figs 7 and 8). Furthermore, in eleven of these thirteen tracts, the more stimulated oviduct was on the side contralateral to the most recent CL. This may have been a reflection of the fact that $59.2 \%$ of the ovulations tended to be from the ovary opposite to that containing the previous CL. When the Graafian follicle or a tertiary follicle showing changes indicative of its probable development into the Graafian follicle (e.g. a close application of thecal capillaries to the basement membrane of the granulosa) were evident, the stimulated oviduct was always the proximal one.

Immediately after ovulation, the ampulla of the oviduct containing the egg was markedly dilated with fluid while the contralateral one was not. This fluid persisted, though in decreasing amount, until Day 3. The laminae propriae of both oviducts were oedematous during this interval (Pl. 2, Figs 9 and 10), but the oedema had largely subsided by Day 4 .

On Day 1, there also appeared to be a transient decrease in the degree of vacuolation of the secretory cells in the oviduct containing the egg relative to those in the contralateral oviduct (cf. Pl. 2, Figs 9 and 10). This was evident even in sections of ampulla not dilated by fluid.

Between Days 4 and 11, the unilateral oviduct reaction was usually pronounced. During the first half of this interval, its most outstanding manifestation was a difference in the degree of vacuolation between the two oviducts (cf. Pl. 2, Figs 11 and 12); invariably, it was greater in the ampulla and isthmus proximal to the CL. Furthermore, the epithelial cells throughout this oviduct were generally larger and contained more vesicular nuclei. The distinctions between nuclear and total cell size in the epithelia of the two oviducts were retained after disappearance of much of the vacuolation and persisted in most tracts until preovulatory changes made their appearance (cf. Pl. 3, Figs 13 and 14,17 and 18).

The vacuoles did not entirely disappear in the oviduct contralateral to the cL. In fourteen of twenty-six tracts from bats killed between Days 10 and 14 inclusive, some vacuolation persisted in the epithelial cells of the ampulla and 
isthmus on this side (cf. Pl. 3, Figs 13 and 14). This distinction continued to be apparent until the 24th day of pregnancy, the latest stage examined.

Possibly because of the tendency towards alternation of ovulations, the preovulatory unilateral oviduct reaction was more likely to involve this oviduct as well, thereby establishing some basis for confusing the pre- and postovulatory phenomena in cycling animals. In the present series, all animals killed after Day 19 of the cycle exhibited sufficient oviducal stimulation both with respect to vacuolation of the secretory cells (cf. Pl. 2, Fig. 7 and Pl. 3, Fig. 14) and hypertrophy of the preampullary epithelium so that the response could be identified as preovulatory. The situation in the small number of animals killed between Days 16 and 18 was ambiguous enough to preclude any such judgement.

TABLE 4

HISTOCHEMICAL REAGTIVITY OF THE OVIDUCT IN $G$. soricina

\begin{tabular}{|c|c|c|c|c|c|}
\hline \multirow[b]{2}{*}{ Component } & \multicolumn{5}{|c|}{ Histochemical test } \\
\hline & $\begin{array}{l}\text { Alcian } \\
\text { blue* }\end{array}$ & $\begin{array}{l}\text { Azure A } \\
\text { pH } 4.5\end{array}$ & $P A S^{*}$ & $\begin{array}{l}\text { Diastase lability } \\
\text { (for glycogen })^{*}\end{array}$ & $\begin{array}{c}\text { Azure B* } \\
(\text { for } R \mathcal{N} A)\end{array}$ \\
\hline $\begin{array}{l}\text { Luminal surface of } \\
\text { epithelium } \\
\text { Vacuoles of bloated } \\
\text { secretory cells (Days } 1 \\
\text { through } 8 \text { to 11) }\end{array}$ & - & - & $\begin{array}{c}++ \\
\text { Few }+ \\
\text { particles }\end{array}$ & partial & - \\
\hline $\begin{array}{l}\text { Involuting secretory } \\
\text { cells (Days } 8 \text { to } 24) \text { : } \\
\text { Apical bulges } \\
\text { Remainder of cells }\end{array}$ & 二 & $\overline{ \pm}$ & $\stackrel{+}{+}$ & $\begin{array}{l}++ \\
+\end{array}$ & \pm \\
\hline
\end{tabular}

* Observations for pregnant animals only.

\section{Histochemical observations}

Except for their apical borders and a few scattered particles of glycogen within the vacuolated regions, the fully bloated ampullary secretory cells failed to react positively with the histochemical methods used in this study (Table 4; Pl. 2, Fig. 11 and Pl. 3, Fig. 16; also see Rasweiler, 1972b). While the vacuolation diminished between Days 8 and 10, glycogen levels increased, particularly within the developing apical bulges. This glycogen was much more concentrated, if not quantitatively more abundant, in the oviduct contralateral to the most recent cL, especially in the ampullae of most animals killed after Day 11 (cf. Pl. 3, Figs 17 and 18). It appeared to be largely responsible for the postovulatory persistence of vacuolated areas in the apical portions of the epithelial cells in the contralateral oviduct.

\section{DISGUSSION}

\section{Tubal journey of the ovum}

In most mammals for which data are available, the tubal journey of the ova occupies from 3 to 5 days (Blandau, 1969). Transport through the oviduct is 
slower in the dog, 6 to 8 days, and the cat, 5 to 7 days (Austin, 1969). In the weasel, Mustela frenata, morula stages have been found in the oviduct on Day 11 (Wright, 1948). Wimsatt (1944) estimated that implantation in the Vespertilionid bat, Myotis lucifugus, began not less than 10 days after ovulation.

Since menstruation in $G$. soricina occurs at or very close to the time of ovulation, the long tubal journey of the ovum and slow rate of embryonic development in this species are presumably adaptations which permit regeneration of the endometrium before the arrival and implantation of the ovum.

\section{Loss of the zona pellucida and its retention in the oviduct}

In most other mammals, loss of the zona pellucida is normally a uterine phenomenon (Boyd \& Hamilton, 1952; Enders \& Schlafke, 1969; Dickman, 1969). The only exceptions previously reported were for the elephant shrew, Elephantulus myurus jamesoni (van der Horst, 1942), the tarsier, Tarsius spectrum (Hubrecht, 1902, cited in Boyd \& Hamilton, 1952), and the vampire bat, Desmodus rotundus (Wimsatt, 1954). However, the observations for E. myurus were probably the result of fixation artifacts (Tripp, 1971). Loss of the zona from mouse blastocysts will occur in vitro and in extrauterine sites (Dickman, 1969). Since ectopic pregnancies are common in humans (Benirschke, 1969; Woodruff \& Pauerstein, 1969), the blastocyst of this species must possess the ability to lose the zona in extrauterine sites.

This phenomenon may have developed in G. soricina (1) to prevent the zona from interfering with the initial attachment of the blastocyst at its implantation site within the restricted confines of the uterotubal junction, (2) because loss of the zona could be a prerequisite for escape of the ovum from the ampulla, or (3) simply as a reflection of the advanced state of development reached by the embryo in the oviduct.

The observations that only living ova are transported through the oviduct of G. soricina and the mare (Rowson, 1971) reveal a level of sophistication of the ovum transport mechanism not appreciated from work with other species. Possibly, the selection process relies upon physical differences between the living ova and degenerating ones or discarded zonae. It is also conceivable that the ovum could play a more active rôle, mechanically or chemically stimulating a localized portion of the wall of the oviduct to assist its passage into the uterus. Support for the latter theory comes from the observation of an apparent local effect of the early sheep embryo upon uterine motility (Cloud \& Casida, 1969). Furthermore, Humphrey (1970) noted in the mouse a localization of both fluid and strong peristaltic contractions in the vicinity of the oviducal loops containing the ova.

\section{Cytology of the oviduct}

The B cells observed in $G$. soricina appear very similar to the 'clear cells' shown to be precursors of the mature ciliated cells in the oviduct of the rhesus monkey (Brenner, 1969). This use of the term 'clear cell' would seem to be unfortunate, since it had previously been utilized to describe cells in the uterine and other visceral epithelia that resemble the oviducal basal cells (Rasweiler, 1972b). 
Unlike the situation in the rhesus monkey, there is no widespread cyclic deciliation of the epithelial cells in any portion of $G$. soricina's oviduct. Possibly, partial deciliation of individual cells occurs, and the $\mathbf{B}$ cells represent a stage of such cells developing new cilia. It is also conceivable that some B cells may have been recently formed by mitosis and were undergoing ciliogenesis.

The histochemical results indicate that the vacuolated areas in the fully developed secretory cells do not contain substantial amounts of glycogen, glycoprotein or acid mucopolysaccharides. Thus, the secretory cells of this bat are quite different from those of other mammals (Greenwald, 1969; Fredricsson, 1969).

\section{Cyclic histological changes}

The appearance of free cells in the oviduct lumen at oestrus suggests that there may be increased ciliary action during this portion of the cycle, which can sweep them into the oviduct from the peritoneal fluid. Evidence for such a current has been observed in other species (Alden, 1942; Blandau, 1961; Humphrey, 1968).

Similarly, dilatation of the oviduct at oestrus (Blandau, 1961) and increased secretion of oviducal fluid (Bishop, 1969; Hamner \& Fox, 1969; McDonald \& Bellvé, 1969) have previously been noted but no mention was made of any differences between the two oviducts in uniparous species. In ovariectomized rabbits, the secretion rate was increased to 'oestrus' levels by the administration of oestrogen and was inhibited by progesterone (Hamner \& Fox, 1969).

The endocrine control of the phenomenon in $G$. soricina could be similar with the local effect being due to one or more of the following factors: (1) higher oestrogen levels reaching the oviduct proximal to the Graafian follicle or new GL through points of 'fusion' between the ovary and oviduct: (2) peculiarities of the blood or lymphatic drainage of the ovary which permit local stimulation of the proximal oviduct; (3) direct stimulation of the oviduct by hormones in the follicular fluid or released by the cumulus or granulosa cells; (4) physical and/or chemical (i.e. non-steroidal) stimulation by the egg, the cumulus or granulosa cells, or the follicular fluid.

The temporal sequence of changes in the oviducal secretory cells suggests that the vacuolated areas may develop more completely in the oviduct proximal to the Graafian follicle because of the higher oestrogen levels existing there. They may then be more thoroughly dissipated on the side proximal to the GL because of higher progesterone titres. Replacement therapy in ovariectomized rabbits (Greenwald, 1969; Koester, 1970) and cows (McDaniel, Scalzi \& Black, 1968) has shown that hypertrophy of the oviduct and the synthesis of secretory products occurred after oestrogen treatment, whereas progesterone effected release of the secretion.

The apparent decrease noted immediately after ovulation in the degree of vacuolation of the secretory cells in the oviduct containing the egg may have been a response to progesterone introduced with the follicle contents. In other species, progesterone has been shown to be present in the follicular fluid (Short, 1964; Channing, 1969).

The histochemical observations suggest that glycogen mobilization from the 
secretory cells of the oviduct proximal to the CL may also be stimulated preferentially by progesterone. The PAS reaction was not performed on appropriately fixed, non-pregnant reproductive tracts. Comparison of pregnant and nonpregnant tracts, however, indicated that in both types a similar disparity existed between the two ampullae with respect to the degree of apical vacuolation of the secretory cells (thought to be due to the presence of glycogen). This would seem to weigh against the possibility that the living ovum, rather than endocrine factors, is the active agent in bringing about dissipation of the glycogen. There still remains the possibility that the presence of a degenerating ovum could have induced such changes in the non-mated bats.

\section{ACKNOWLEDGMENTS}

This research was supported in part by NIH Training Grant HD00171-04 and by NSF Research Grant GB-6435X to Dr William A. Wimsatt. The assistance of Mr Anthony Guerriere, Miss Kathryn Martin and Dr William A. Wimsatt is gratefully acknowledged. Thanks are also due to Dr Hugh Tyndale-Biscoe for critically reading the manuscript.

\section{REFERENCES}

Alden, R. H. (1942) The oviduct and egg transport in the albino rat. Anat. Rec. 84, 137.

Anderson, S. \& Jones, J. K. (1967) Recent mammals of the zorld. Ronald Press, New York.

Austin, C. R. (1969) Fertilization and development of the egg. In: Reproduction in Domestic Animals, 2nd edn. pp. 355-384. Eds. H. H. Cole and P. T. Cupps. Academic Press, New York and London.

Benirschre, K. (1969) Pathologic processes of the oviduct. In: The Mammalian Oviduct, pp. 271-307. Eds. E. S. E. Hafez and R. J. Blandau. University of Chicago Press.

Brshop, D. W. (1969) Sperm physiology in relation to the oviduct. In: The Mammalian Oviduct, pp. 231-250. Eds. E. S. E. Hafez and R. J. Blandau. University of Chicago Press.

Blandau, R. J. (1961) Biology of eggs and implantation. In: Sex and Internal Secretions, Vol. II, pp. 797882. Ed. W. G. Young. Williams \& Wilkins, Baltimore.

Blandau, R. J. (1969) Gamete transport-comparative aspects. In: The Mammalian Oviduct, pp. 129162. Eds. E. S. E. Hafez and R. J. Blandau. University of Chicago Press.

Boyd, J. D. \& Hamilton, W. J. (1952) Cleavage, early development and implantation of the egg. In: Marshall's Physiology of Reproduction, Vol. 2, pp. 1-126. Ed. A. S. Parkes. Longmans, Green, London.

BRADshaw, G. V. R. (1962) Reproductive cycle of the California leaf-nosed bat, Macrotus californicus. Science, $\mathcal{N} . \Upsilon .137,645$.

Brenner, R. M. (1969) The biology of oviductal cilia. In: The Mammalian Oviduct, pp. 203-229. Eds. E. S. E. Hafez and R. J. Blandau. University of Chicago Press.

Channing, C. P. (1969) The use of tissue culture of granulosa cells as a method of studying the mechanisms of luteinization. In: The Gonads, pp. 245-275. Ed. K. W. McKerns. Appleton-Century-Crofts, Educational Division, Meredith Corporation, New York.

Gloud, J. G. \& GAsIDA, L. E. (1969) Local effect of the early sheep embryo upon uterine motility. F. Anim. Sci. 29, 48.

Dickman, Z. (1969) Shedding of the zona pellucida. In: Advances in Reproductive Physiology, Vol. 4, pp. 187-206. Ed. A. McLaren. Logos Press, London.

ENDERs, A. C. \& SchlaAfKe, S. (1969) Cytological aspects of trophoblast-uterine interaction in early implantation. Am. 7. Anat. 125, 1.

FLAX, M. H. \& Hmes, M. H. (1952) Microspectrophotometric analysis of metachromatic staining of nucleic acids. Physiol. Zoöl. 25, 297.

Fleming, T. H. (1971) Artibeus jamaicensis: delayed embryonic development in a neotropical bat. Science, N.Y. 171, 402.

Fredericsson, B. (1969). Histochemistry of the oviduct. In: The Mammalian Oviduct, pp. 311-332. Eds. E. S. E. Hafez and R. J. Blandau. University of Chicago Press.

Greenwald, G. S. (1969) Endocrinology of oviductal secretions. In: The Mammalian Oviduct, pp. 183-201. Eds. E. S. E. Hafez and R. J. Blandau. University of Chicago Press.

HAmLeTt, G. W. (1934a) Implantation und Embryonalhüllen in zwei südamerikanischen Fledermausen. Anat. Anz. 79, 146. 
Hamlett, G. W. (1934b) Uterine bleeding in a bat Glossophaga soricina. Anat. Rec. 60, 9.

HamLETr, G. W. (1935) Notes on the embryology of a phyllostomatid bat. Am. F. Anat. 56, 327.

Hamner, C. E. \& Fox, S. B. (1969) Biochemistry of oviductal secretions. In: The Mammalian Oviduct, pp. 333-355. Eds. E. S. E. Hafez and R. J. Blandau. University of Chicago Press.

HuMphREY, K. W. (1968) Observations on transport of ova in the oviduct of the mouse. F. Endocr. 40, 267.

Humphrey, K. W. (1970) Mechanisms concerned in ovum transport. In: Schering Symposium on Mechanisms Involved in Conception, pp. 133-148. Ed. G. Raspé. Pergamon Press, Oxford.

Koester, H. (1970) Tubal secretion and egg development. In: Schering Symposium on Mechanisms Involved in Conception, pp. 181-198. Ed. G. Raspé. Pergamon Press, Oxford.

LILlIE, R. D. (1965) Histopathologic technic and practical histochemistry. McGraw-Hill, New York.

McDaniel, J. W., Scalzi, H. \& Black, D. L. (1968) Influence of ovarian hormones on histology and histochemistry of the bovine oviduct. 7. Dairy Sci. 51, 754.

McDonald, M. F. \& Bellvé, A. R. (1969) Influence of oestrogen and progesterone on flow of fluid from the Fallopian tube in the ovariectomized ewe. 7. Reprod. Fert. 20, 51.

NiLsson, O. \& ReInius, S. (1969) Light and electron microscopic structure of the oviduct. In: The Mammalian Oviduct, pp. 57-83. Eds. E. S. E. Hafez and R. J. Blandau. University of Chicago Press.

RASWEILER, J. J., IV (1970) The laboratory biology of the long-tongued bat, Glossophaga soricina: maintenance procedures, estivation, the menstrual cycle, histophysiology of the oviduct and intramural implantation. Ph.D. thesis, Cornell University, Ithaca, New York.

Rasweiler, J. J., iv (1972a) The care and management of the long-tongued bat, Glossophaga soricina (Chiroptera: Phyllostomatidae) in the laboratory, with observations on food deprivationinduced estivation. 7. Mammal. (in press).

Rasweiler, J. J., Iv (1972b) The basal or indifferent cell, and the ciliary vacuole in the oviducal epithelium of the long-tongued bat, Glossophaga soricina. F. Reprod. Fert. 30, 191.

RAsWeILER, J. J., IV (1973) The care and management of bats as laboratory animals. In: The Biology of Bats. Ed. W. A. Wimsatt. Academic Press, New York and London.

Rowson, L. E. A. (1971) The rôle of reproductive research in animal production. 7. Reprod. Fert. 26, 113.

Short, R. V. (1964) Ovarian steroid synthesis and secretion in vivo. Recent Prog. Horm. Res. 20, 303.

TAmsits, J. R. \& Valdivieso, D. (1965) Reproduction of the female big fruit eating bat, Artibeus lituratus palmarum in Colombia. Caribb. J. Sci. 5, 157.

TRIPP, H. R. H. (1971) Reproduction in elephant shrews (Macroscelididae) with special reference to ovulation and implantation. F. Reprod. Fert. 26, 149.

vAN DER HoRst, C. J. (1942) Early stages in the embryonic development of Elephantulus. S. Afr. F. med. Sci. 7, 55. Biol. Suppl.

Wimsatt, W. A. (1944) An analysis of implantation in the bat, Myotis lucifugus lucifugus. Am. F. Anat. 74, 355.

Wimsatr, W. A. (1954) The fetal membranes and placentation of the tropical American vampire bat Desmodus rotundus murinus with notes on the histochemistry of the placenta. Acta anat. 21, 285.

WISLOCKI, G. B. \& FAWCETT, D. W. (1941) The placentation of the Jamaican bat (Artibeus jamaicensis parvipes). Anat. Rec. 81, 307.

Woodrupr, J. D. \& Pauerstein, C. J. (1969) The Fallopian tube. Williams \& Wilkins, Baltimore.

Wright, P. L. (1948) Preimplantation stages in the long-tailed weasel (Mustela frenata). Anat. Rec. 100, 593. 